\title{
The Evaluation of Resettlement Populations on the Income of Settler's in Sasiga Woreda, East Wollega Zone, Oromia Regional State, Ethiopia
}

\author{
Lelisa Mamo Abdisa \\ Masters of Science in Development Economics, Department Head of Economics, Faculty of Business and Social \\ Science, Rift Valley University, Nekemte Campus, P.O. Box 648, Nekemte, Ethiopia
}

\begin{abstract}
The study evaluated the burden of resettlement Populations on the settler's income in Sasiga Woreda of East Wollega Zone Oromia, Ethiopia. Some of the resettlement schemes around the world failed, while some others were successful. The objective of the study was to identify facators that cause resettlement and evaluate the burden of resettlement on the settler's's annual income in study area. The study was based on cross-sectional data collected from a sample of 140 settlers (81 were Populations participants and 59 were non-Populations participants) using purposive and stratified random sampling techniques. Descriptive statistics and econometric models were employed to analyze the data. The Logit model indicated education status of the settlers, availability of credit access, availability of agricultural inputs, land farm size holding by settler's, farm income of settler's were negatively and significantly related to Populations participation while shocks, livestock holding by settler's, access of extension service, and total asset of settler's were positively affect and significantly associated with Populations participants. Propensity score matching shows, that the average annual income of resettlement Populations participants more than income of non participant by 29,182.6463 ETB. Based on the findings, the study suggests that strengthening the encouragement of resettlement Populations have crucial role towards improving the income of settlers in the study area. Finally, the policy implication of the study is that income sources diversification, incorporated development Populations, practical based extension service delivery, access to credit service for the purchase of agricultural inputs and its preparations are needs policy attention.
\end{abstract}

Keywords: Resettlement Populations me, Propensity score matching, Settlers' income, Sasiga Woreda.

DOI: $10.7176 / \mathrm{JESD} / 11-17-03$

Publication date:September $30^{\text {th }} 2020$

\section{INTRODUCTION}

Resettlement is a population movement planned directly by the government or private developers, where an area is chosen in order to resettle the population (Sherbinin et al., 2010). If, resettlement is effectively used, it is a vital to realize these entire notions, and to proactively plan for resettlement as part of equipped protection approach (UNHCR, 2012). The effect of resettlement is more on women than men (Bisht, 2009, Terminski 2013). The resettled settlers have restricted options to rebuild their livelihoods (Wilmsen et al. 2011 and 2015) Ogwang et al. 2018b).

Many African governments to respond to the mismatch of Population numbers and environmental conditions, inter alia, to cope with landscapes that could not sufficiently care for their inhabitants have employed resettlement (Tilt B, 2016).

The other way of resettlement scheme would be implemented through centrally planned coordination of the government policy intervention. This was really practiced in Ethiopia at different administrative regimes where the areas were selected by resettlement administering authorities, without consultation of the host communities and assessment of the area (Adugna M. 2012). On the other hand, a change in any one of these assets may result in a difference in the income assets of the settlers either positively or negatively (Zeleke,T., 2014,P 36).

\subsection{STATEMENT OF THE PROPLEMS}

As several researchers have tried to assess the resettlement schemes and identified practical evidences on factors affecting success or failure of resettlement Populations s, some of the resettlement schemes around the world failed, while some others were successful. This is due to the proper planning, site selection, size of land allocated to settlers, land tenure and farming systems, management and administration. (Woldeselassie, 2014, Gebregzihabher, 2014). In China, studies found that resettlement is associated with a range of negative burden s on communities, such as reduced land holdings (Tilt, B.; Gerkey, D, 2016), reduced access to natural resources and ecological services (Wilmsen, B.; Webber, M.;2015 and Yuefang, D. 2011), declined settler's incomes (Sikka, G.; Mathur, $\mathrm{V}, 2015$ ). Besides, McDonald et al. (2018) investigated different villages after resettlement and found that some villages have higher incomes than others. Most existing literature on resettlement in developing regions, including Africa, has focused on the general effects (Quetulio-Navarra et al. 2014; Kyomugasho 2016: Ogwang et al. 2018a). A major cause of resettlement in Africa is the exploitation and transportation of raw materials and the creation or 
expansion of conservation areas. During the 1970 s and 80 s, the most drought stricken areas were limited to northern Ethiopia, especially Wallo and Tigray. Previous studies found that resettlement have negative burden $\mathrm{s}$ on the socio-economic conditions of the local regions (FAO, 2016). For instance, Desalegn (2018) identified that resettlement would cause disruption by causing impoverishment of host communities, destruction of productive assets, and disruption of the social fabric. Dwivedi (2017) added that resettlement could result in asset and job losses, the breakdown of the social and food security, credit, labor exchanges, networks, social capital and kinship ties. In addition, Heggelund (2010) found that the resettlement in Three Gorges Project displaced local people to dissimilar places, which caused their social networks to become disconnected and also led to potential variation with the new host community. Studies by Kassahun and Shiferaw (2017) shows that relocation was said to have preserve the life and was a dark spot in the settlement history of the country.

The suffering brought by displacement and resettlement makes it hard for the women to adapt in the new environment (Terminski 2013). A study by Ogwang et al. (2018b) in the Albertine region of Uganda indicated that shortage of land and exploitation of the cash from compensation on treaties and freedom by men led to family collapse. The resettled settlers have limited options to reconstruct their livelihoods (Wilmsen et al. 2011). A study by Yankson et al. (2018) indicated that several challenges such as water scarcity, decreased access to forest products such as charcoal and firewood, and reduced access to fertile soils constrain the coping strategies of resettled communities. Therefore, this research contributes to fill the gap in the literature in this regard. So the research goal is to respond the following research questions:

\subsection{RESERCH QUESTIONS}

1. Did resettlement affect the income level of the settlers? If yes, by what amount (positively or negatively?)

2. What are the burden of the resettlement Populations me on the settler's's annual income?

\section{RELATED LITARACTURE REVIEW}

\subsection{Resettlement at the international level}

Resettlement is a lifeline open to some of the world's most vulnerable refugees (InaStrøm, 2017). According to the WBED report, transportation was the cause of 24.6 percent of resettlement projects between financed by World Bank and active in 1993. Resettlement is recognized today as a vital instrument of international protection, integral to comprehensive protection and durable solutions strategies(UNHCR, 2011, 2017). In 2010, a massive earthquake in Haiti displaced over 1.5 million people. By 2012, more than 100,000 transitional shelters had been built across Haiti and 420,000 individuals had resettled in the United States of America. Extreme weather events in 2015 and 2016 further affected food access and agricultural production (NMUN.NY, 2016).

\subsection{Resettlement in Africa}

In Africa, resettlement is a serious matter of current as well as future concern. Africa's share of displaced people has been exceptionally high (Ohta and Gebre 2005). In some cases, local congestion was so serious that people were no longer able to produce enough food to feed their families and had to be assisted with food by the government (Mwiza, 2010). Resource redistribution is also another factor for displacement. The contested land reform and resettlement Populations me of Zimbabwe and Namibia is a typical example (Chimhowu and Hulme 2006).

\subsection{Resettlement in Ethiopia}

Resettlement under the Imperial regime: The major objective of the plan was not food insecurity and famine as they were principal causes in the later government rather to relive population pressures in the highlands (Desalegn, 2003b). Nevertheless, these were habitually small in size, informal in nature, and were mainly designed to achieve specific and limited objectives (Berhane 2003). Resettlement under the Derge: The basic rational to design the policy of the Derg in relation to resettlements was the defective estimate of unutilized and underutilized land resources found particularly in the southwestern parts, and south of Ethiopia. Resettlement under the EPRDF:The basic assumptions behind the current resettlement Populations me remain similar to those made during previous periods (Imperial and Derg regime). Official declaration, voluntary resettlement is view as a main and essential factor of endeavours aimed at addressing the paramount problem of food insecurity in Ethiopia (GFDRE 2001).

\subsection{Cause of the resettlement in Ethiopia}

The official objective of resettlement plans in Ethiopia, both in the past and current regimes, as stated in various documents, was to prevent famine or attain food security) by moving people from drought-prone and overloaded areas to lightly populated regions and unoccupied virgin lands (Yntiso 2002). The rapid population growth particularly in rural areas has decreased the size of land holding leading to landlessness and deterioration of the environment which were considered as causes of migration and resettlement (Ahmed Mohammed, 2005). 


\subsection{Functions of Resettlement}

States are not obliged to accept refugees for resettlement, but rather voluntarily offer resettlement places as a tangible expression of international solidarity (UNHCR, 2014). Following the resettlement Populations there is considerable damage to the natural vegetation of the study area. Large areas are cleared of their vegetation for crop production, to build homesteads and to acquire fuel wood (Haile, 2007).

\section{METHODOLOGY}

The researcher was used qualitative and quantitative data and cross-sectional design. The data had been collected using open ended and closed ended questionnaires. For the analysis of the data both descriptive and econometric analyses was employed. The sampling frame for this study was rural resettled and non settled settlers that are living in lowland/kola. The study was employed different sampling techniques to select the representative samples due to obtain both residents. Sasiga woreda has 27 kebeles of which 26 was rural and one (1) were Town kebeles having resettlement dwellers. Firstly, the Sasiga Woreda was purposively selected. In addition to this, three kebeles which had settler's and non-settler's populations namely, Gudina, Bareda, Shonkora had been selected from 27 kebeles of the Woreda purposively and by simple random sampling. The selection of these kebeles are due to the majority of the settlers dwellers are new resettles', which were settled in 1995EC/2003GC coming from Western Harargeh and the origin populations were less than these settlers. The total populations survive in the selected kebeles were 13145. The sample frame of the settlers and non-settlers from the three kebeles were 13,142 from these (5764) settler populations and (7378) original populations of which 2657 male and 4721 female nonsettlers and 2567 male and 3197 settlers). From the total population 13142of the three kebeles 5,224 are male and 7,918 female. Thirdly, adequate Respondent settlers had been selected from both settlers and non-settlers by using systematic Random sampling techniques from selected kebeles. Hence, 140 settlers had selected randomly for the study from these sample kebeles including both male and female-headed settlers (Source: Sasiga Woreda office, 2020).

\subsection{Methods of Data Analysis}

The study was employed both descriptive statistics and Econometric model. Statistical descriptions like table, graph, frequency descriptive, inferential statistical methods and percentages, Logit model and Propensity Score Matching method (PSM) were employed for analyzing and interpreting the data.

Conventionally, linear regression analysis was widely used in most economic and social investigation because of availability of simple computer packages, as well as ease of interpreting the results. However, according to Amemiya (1981), Maddala (1997) and Gujarati(2004) the linear probability model has an obvious defect in that the estimated probability values can lie outside the normal 0 -1range and that it models the probability of $Y=1$ as being linear: $\operatorname{Pr}(\mathrm{Y}=1 \mid \mathrm{X})=\beta_{0}+\beta_{1} \mathrm{X}$.

\subsection{Econometric Model Specification}

The study was affected by the independent variables such as demographic factors, social factors, Economic factors, and sources of income factors, settler's education, and factors causes' resettlement. The major pillars of this model are individuals, treatment and potential outcomes. The treated settlers were from the resettlement Populations participants and the control group will from the non-participants for comparison. In order to overcome the problem Propensity score matching method will be applied for burden evaluation in the absence of baseline survey data. Imbens (2000) and Lechner (2001) when leaving the binary treatment case the choice of multinomial logit is quite easier to analyze dichotomous variables and approaches relatively preferable mathematical performance to estimate. In the cause of binary treatment the treatment indication Di equals 1 if individual $\mathrm{i}$ received treatment and 0 otherwise.

The potential outcomes were then defined as $\mathrm{Yi}$ (Di) for each individual $\mathrm{i}$, where $\mathrm{i}=1 \ldots, \mathrm{N}$ and $\mathrm{N}$ denoted the total population. The treatment effect for an individual $\mathrm{i}$ was written as:

$\mathrm{T}=\mathrm{Y}(1)-\mathrm{Y}(0)$

A logit model would be used to estimate propensity scores using a composite of pre-intervention characteristics of the sample settlers (Rosenbaum and Rubin, 1983) and matching was then performed using propensity scores of each observation. In estimating the logit model, the dependent variable was resettlement Populations me participation, which took the value of 1 if a settler's participate in resettlement and 0 otherwise. The specification of the logit model was as follows:

We begin from the linear probability model of the form:

$$
P(y=1 / x i)=\mathrm{Zi}=\beta_{0}+\beta_{1} x_{1}+\beta_{2} x_{2}+---+\beta_{k} x_{k}
$$

\section{$P i=\frac{1}{1+e^{-z i}}$ is simplified to:}


$P i=\frac{e^{z i}}{1+e^{z i}}$

Where, Pi is the probability that the $i^{\text {th }}$ settlers will participate in resettlement, $z_{i}$-is a linear function of ' $n$ ' explanatory variables $(\mathrm{x})$ and will be expressed as:

$$
\mathrm{Zi}=\beta_{0}+\beta_{1} x_{1}+\beta_{2} x_{2}+---+\beta_{k} x_{k}+U i
$$

Where, $\beta \mathrm{o}$-intercept, $\beta i$-regression coefficients to estimate, $\mathrm{U}_{\mathrm{i}}-$ is an error term.

$1-P i=\frac{1}{1+e^{-z i}}$ is simplified to:

$1-P i=\frac{1}{1+e^{z i}}$

Where $1-\mathrm{Pi}$ is the probability that a settler's belongs to the non-Populations me participant.

$\frac{P i}{1-P \mathrm{i}}=\left(\frac{1+e^{z i}}{1+e^{-z i}}\right)=e^{z i}$ or

$\operatorname{Or}\left(\frac{\mathrm{Pi}}{1-\mathrm{Pi}}\right)=\left(\frac{\mathrm{e}^{\mathrm{zi}}}{1+\mathrm{e}^{-\mathrm{zi}}}\right)=\mathrm{e}^{\left(\beta_{0}+\beta_{1} x_{1}+\beta_{2} x_{2}+---+\beta_{k} x_{k}\right)}$

This is known as Odds ratio. Taking the natural logarithm of the Odds ratio, thelogit model is:

$$
\mathrm{Li}=\ln \left[\frac{\mathrm{Pi}}{1-\mathrm{Pi}}\right]=\ln \mathrm{e}^{\left(\beta_{0}+\beta_{1} x_{1}+\beta_{2} x_{2}+---+\beta_{k} x_{k}\right)}=\beta_{0}+\beta_{1} x_{1}+\beta_{2} x_{2}+---+\beta_{k} x_{k}
$$

Where $\mathrm{x}_{1}, \mathrm{x}_{2}, \ldots \ldots \ldots \ldots \ldots . . . . . \mathrm{x}_{\mathrm{k}}$ are demographic, social and Economic factors that cause resettlement which will be included in the above econometric model.

\subsection{Evaluation the burden of resettlement on income of settler population Propensity scores and PSM}

Prior to analyzing the burden of resettlement Populations by employ PSM matching algorithms, logit regression model is used as a necessity to identify the Populations participant's annual income in order to understand the importance of resettlement Populations. The model is estimated with STATA software using the propensity scorematching algorithm developed by Leuven and Sianesi (2003). Propensity score matching (PSM) build a statistical evaluation group that is based on a model of the probability of participating in the treatment, using observed characteristics. Population's participants are then matched on the basis of this probability, or propensity score, to nonparticipants of the Populations. The average treatment effect of the Populations is then deliberate as the mean distinction in outcomes across these two groups. The validity of PSM depends on two circumstances: (a) conditional independence (namely, that unseen factors do not affect participation) and (b) sizable common support or overlap in propensity scores across the participant and nonparticipant samples (Shahidur R. Khandker,Gayatri B. Koolwal \& Hussain A. Samad, 2010).

Relocated people suffer from the loss of farmland, forestland, houses and other properties, which may then reduce their income (Wang, P, 2013, Tilt and Gerkey 2016). McDonald et al. (2018) found resettlement could have positive burden s on maintaining and raising the income level of the resettled community. Galipeau et al. (2013) compared the distinction between a resettled community and a non-resettled community in term of income and landholding, showing that resettled communities have a higher income level.

The establishment of this counterfactual often creates problems where before intervention situation remains missing. Burden through this outcome variable was obtained by matching an ideal comparative group (non-settler farmers) to the treatment group (settler farmers) based on propensity scores (P-scores) of X. X was the set of observable characteristics that determine settlement participation. By so doing, the selectivity bias was largely eliminated.

Equation 1 below presented the basic evaluation problem comparing outcomes $Y$ across treated and nontreated individuals $i$ : 
$\mathbf{Y}_{\mathbf{i}}=\boldsymbol{\alpha} \mathbf{X}_{\mathbf{i}}+\beta \mathbf{T}_{\mathbf{i}}+\varepsilon_{\mathbf{i}}$

Here, $\mathrm{T}$ is a dummy equal to 1 for those who participate in resettlement Populations and 0 for those who do not participate in the Populations. $\mathrm{X}$ was set of other observed characteristics that determine participation in resettlement and ' $\varepsilon$ ' is an error term reflecting unobserved characteristics that also affect Y.To develop the PSM model, let $Y_{i}$ be the outcome variable of settler's $i$, such that $Y_{1 i}$ and $Y_{0 i}$ denote settler's outcomes with and without participating in resettlment, respectively. A dummy variable $T_{i}$ denotes rettlement participation by settler's $i$, where $\mathrm{T}_{\mathrm{i}}=1$ if the settler's had participated in resettlement and, $\mathrm{T}_{0}=0$, otherwise. The outcome observed for settler's $i$, $\mathrm{Y}_{\mathrm{i} w a s}$ defined by the switching regression (Quandt, 1972).

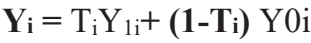

The burden of resettlement on income of settler i's is given by;

$\Delta_{\mathrm{i}} \mathbf{Y}_{\mathbf{i}}=\mathbf{Y}_{1 \mathrm{i}}-\mathbf{Y}_{\mathbf{0}}$

Where, $\Delta_{\mathbf{i}} \mathbf{Y}_{\mathbf{i}}$ denotes the change in the outcome variable of farmer $\mathrm{i}$, resulting from participation in resettlement. A farmer cannot be both ways, therefore, at any time, either $\mathbf{Y}_{\mathbf{1 i}}$ (resettling farmer) or $\mathbf{Y}_{\mathbf{0}}$ (non-resettling famer) is observed for that farmer. This gives rise to the selectivity bias problem (Heckman et al., 1997). For this study, ATT was used to estimate the burden of rettlement on income of settler population and it was represented as follows:

$\mathrm{ATT}=\left\{\mathrm{E}\left(\Delta_{\mathrm{i}} \mid \mathrm{I}_{\mathrm{i}}=1\right)\right\}=\mathrm{E}\left\{\mathrm{Y}_{1 \mathrm{i}}-\mathrm{Y}_{0 \mathrm{i}} \mid \mathrm{I}_{\mathrm{i}}=1\right\}=\mathrm{E}\left\{\mathrm{Y}_{1 \mathrm{i}} \mid \mathrm{I}_{\mathrm{i}}=1\right\}-\mathrm{E}\left\{\mathrm{Y}_{0 \mathrm{i}} \mid \mathrm{I}_{\mathrm{i}}=1\right\}$

From equation (4), $\mathrm{E}\left\{\mathrm{Y}_{0 \mathrm{i}} \mathrm{I}_{\mathrm{i}}=1\right\}$ was the missed data representing the outcomes of non-resettling group. The outcomes of non-resettling farmers could rewritten as:

$\mathrm{E}\left\{\Delta_{\mathrm{i}} \mid \mathrm{I}_{\mathrm{i}}=1\right\}=\mathrm{E}\left\{\mathrm{Y}_{1 \mathrm{i}} \mid \mathrm{I}_{\mathrm{i}}=1\right\}-\mathrm{E}\left\{\mathrm{Y}_{0 \mathrm{i}} \mid \mathrm{I}_{\mathrm{i}}=1\right\}$

However, a bias of the magnitude indicated in equation (6) below results when non-resettling farmers were selected for comparison with settling farmers, without controlled for the non-random resettlement assignment (Namara, 2014).

$\operatorname{Bias}=\mathrm{E}\left\{\Delta_{\mathrm{i}} \mid \mathrm{I}_{\mathrm{i}}=1\right\}+\left\{\mathrm{E}\left[\mathrm{Y}_{0 \mathrm{i}} \mid \mathrm{I}_{\mathrm{i}}=1\right]-\mathrm{E}\left[\mathrm{Y}_{0 \mathrm{i}} \mid \mathrm{I}_{\mathrm{i}}=0\right]\right\}$

Finally, up on establishing common support for the resettler farmers, the ATT of resettlement on settlers' income can then be estimated using the following equation:

$$
A T T=\left[E\left(\Delta_{i} \mid \mathbf{I}_{\mathrm{i}}=1\right]=\frac{1}{I_{i}} \sum\left(Y_{\mathrm{o} i}\right) I_{i}=\frac{1}{I_{i}} \sum \Delta_{i} \mathrm{I}_{\mathrm{i}}\right.
$$


Table 3.1: Summary of Variables included in the models

\begin{tabular}{|c|c|c|c|c|}
\hline $\mathrm{S} / \mathrm{n}$ & \multicolumn{2}{|c|}{ Variable } & Units of measurement & Expected Sign \\
\hline 1 & Progptn & $\begin{array}{l}\text { participation in resettlement } \\
\text { Populations me }\end{array}$ & $\begin{array}{l}\text { Dummy (Populations participant }=1 \text {, } \\
\text { not participant }=0 \text { ) }\end{array}$ & \\
\hline 2 & Totinc & $\begin{array}{l}\text { Total annual income(outcome } \\
\text { variable ) }\end{array}$ & $\begin{array}{l}\text { Continuous: Measured in Birr or total } \\
\text { annual income in birr. }\end{array}$ & \\
\hline 3 & Gen & Gender of settler's & Dummy: 1 if male, 0 otherwise & -ve \\
\hline 4 & Age & Age of house hold head & Continuous Measured in year & $+\mathrm{ve} /-\mathrm{ve}$ \\
\hline 5 & Educ & Educated settler's & $\begin{array}{l}\text { Dummy: } 1 \text { if Literate }, 0 \text { Otherwise } \\
\text { ( Illiterate) }\end{array}$ & $+\mathrm{ve}$ \\
\hline 6 & Famsize & Family size of settler's & Continuous & $+\mathrm{ve} /-\mathrm{ve}$ \\
\hline 7 & Farmsize & Farm size & Continuous in hectare & $+\mathrm{ve} /-\mathrm{ve}$ \\
\hline 8 & Shoc & Shocks & $\begin{array}{l}\text { Dummy, } 1 \text { ( if there is drought \& } \\
\text { famine), } 0 \text { otherwise (shortage of land) }\end{array}$ & -ve \\
\hline 9 & Nfarminc & Total Non-farm income & Continuous: measured in br. & $+\mathrm{ve}$ \\
\hline 10 & Farminc & Total farm income & Continuous in $\mathrm{Ku}$ or $\mathrm{Kg}$ & $+\mathrm{ve}$ \\
\hline 11 & Craa & Credit access & Dummy $(\mathrm{No}=0, \mathrm{Yes}=1)$ & $+\mathrm{ve}$ \\
\hline 12 & Extns & Extension service & Dummy $($ access $=1$, no access $=0)$ & $+\mathrm{ve}$ \\
\hline 13 & Acoirrin & Access of irrigation & $\begin{array}{l}\text { Dummy } 1 \text { If irrigation access, } 0 \text { if no } \\
\text { access }\end{array}$ & + ve \\
\hline 14 & Dismark & Distance to market & Continuous: Walk hours & $-\mathrm{ve} /+\mathrm{ve}$ \\
\hline 15 & Livestock & Livestock holding & Continuous measured in TLU & + ve \\
\hline 16 & Totasset & Total settler's asset & 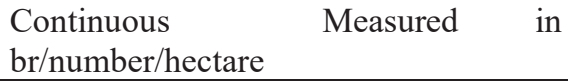 & + ve \\
\hline 17 & Agrinp & Access of agricultural input & $\begin{array}{l}\text { Dummy: } 1 \text { if access to agri. input, } 0 \\
\text { otherwise. }\end{array}$ & + ve/-ve \\
\hline
\end{tabular}

Source: Own Estimation, 2020.

\section{RESULT AND DISCUSSION}

\subsection{Descriptive Analysis of Sample Settlers Characteristics}

The results of descriptive analyses were presented in the form of mean, mean difference, standard deviation, frequency distributions and percentage. The descriptive statistics was runned to observe the distribution of the independent variables. The socio-demographic, socio-economic and institutional characteristics of the respondents' settler's heads were analyzed. The sample under consideration consists of 140 settlers. Of the total, sample respondents $81(57.86 \%)$ were participants of the Populations and $59(42.14 \%)$ were non-participants of the Populations.

Chi-square $(\chi 2)$ and $t$ - statistics tests were used to identify whether the explanatory variables are statistically significant or not significant. The t-test was used to test the significance of the mean value of continuous variables of the two groups of participants and non-participants and chi-square $(\chi 2)$ was used to test the significance of the mean value of the potential discrete (dummy) explanatory variables. Generally, in this section socio-demographic characteristic of sample settlers such as gender of settler's heads, age of settler's heads and total family size; economic characteristics of sample settlers such as livestock holding, farm land size and inputs of production used; settlers characteristics or attributes such as education status of settler's heads and accessibility to information; institutional characteristics such as availability of extension services and credit services characteristics of sample settlers and distance of settler's residence from nearest to water source, nearest to health, nearest to school and nearest market center for discrete as well as continuous variables were analyzed.

\subsection{Settlers Socio-Economic Characteristics}

Settler's farmland size holding: The average mean of land holding of the surveyed settlers equal to 3.69 ha with a minimum of 2 and a maximum of 12 ha. This figure is larger than the average national figure, which is $1.2 \mathrm{ha}$ (CSA, 2008) indicating the existence of relatively higher land holdings in the study area. Even though this figure is over than the national average, there exists a high gap among farmers based on their farmland holdings. The average mean of land size for Populations participants and non-participants were 5.54 and 2.35 respectively with the mean difference of 3.197. The average family size of the surveyed farm settlers equals to 8.06. This is slightly higher than the national average of 6 members (CSA, 2008).

Settlers Livestock Holding: This reveals the total livestock the farmers own in tropical livestock unit. It is a proxy variable for the wealth position of the farmers. The study area was known by mixed crop- livestock farming. 
Average livestock owned in TLU by each farm settler's equals to 7.79. The minimum and maximum livestock owned is 1 and 20, respectively. The draught power used for different farming activities was taken as major source of production in the study area. The settler's farmers with higher number of oxen would be more confident to produce more crop grains rather than counterparts because they had one of the most important factors of production, which creates confidence in hearts of the settler's's farmer for crops production. Majority of farmer settlers attained their income from mixed farming (like beef cattle rearing for commercialization and production, rarely dairy farming, grain crop production and others). The average number of livestock owned by each farmer was equal to 7.79 in TLU with standard error of 0.245 and a $95 \%$ confidence interval of [ $\left.\begin{array}{ll}7.308 & 8.278\end{array}\right]$.

Settler's heads access to Agricultural input (agrinp): Regarding to agricultural inputs from the total sampled settlers $85(60.71 \%)$ access to agricultural inputs while 55 (39.29) farmers were not access to agricultural inputs. The mean difference between those gained agricultural inputs in the Populations participation and nonparticipation were 0.27 . Generally, the null hypothesis' was rejected, due to our variable, access to agricultural input was more important in our study.

Institutional Factors: From the total 140 farm settlers 83 (59.29\%) settlers had been credit access while the remaining $57(40.71 \%)$ settlers did not have access to credit. The mean difference between Populations participants and non-participants on credit access was 0.56 . It is statistically significant at a significance level $1 \%$, $5 \%$ and $10 \%$ [2.624, 1.761, and 1.345] respectively. Therefore Ho: is rejected. It means that our variable was important in our study. Of the total respondents, 105 (75\%) settlers had access to extension while the rest $35(25 \%)$ did not have access to extension. The average mean of credit access of those participating in resettlement Populations were 0.73 while non-Populations participants mean average of access to credit were 0.78 . Usually, the null hypothesis' was rejected, due to our variables (access to credit, and access to extension services) were more vital in our study.

\subsection{Hypothesis testing and econometric model results}

1. Hypothesis Testing

Table 4.1: Summary results of LR test of hypotheses for the aforementioned results

\begin{tabular}{|l|l|l|l|}
\hline Null hypothesis & Calculated LR ratio & Critical LR at 5\% level & Decision rule \\
\hline$\beta_{1}=\beta_{2}=\ldots \beta_{14}=0$ & 139.66 & 6.57 & Reject Ho \\
\hline$\delta_{1}=\delta_{2}=0$ & 8.36 & 0.013 & Reject Ho \\
\hline$\beta_{1}=\beta_{2}=\ldots=\beta_{6}=0$ & 34.56 & 1.635 & Reject Ho \\
\hline
\end{tabular}

Source: Own computation from survey data (2020)

\subsection{Results of Logit model for resettlement Populations participation decision of the sample settlers}

As already mentioned, this study employed the logit model to estimate and conclude the parameters of the determinants of farmers' resettlement Populations participation decision in the study area. The frequency distribution of resettlement Populations participation reveals that out of the 140 total sampled settlers, 81 settlers $(57.86 \%)$ were participants in the Populations while the remaining 59 (42.14\%) were non-participants of resettlement Populations. Thus, the result expose that more than half of the sampled respondents were Populations participants. 
Table 4.2: Estimates of Maximum-likelihood logit model on the determinants of resettlement Populations participation.

\begin{tabular}{|c|c|c|c|c|c|c|}
\hline Progptn & Coef. & Std. Err. & $\mathbf{Z}$ & $\mathbf{P}>\mathbf{Z}$ & {$[95 \%$ Con } & val] \\
\hline Gen & -.1659368 & 1.805019 & -0.09 & 0.927 & -3.703709 & 3.371835 \\
\hline Educ & -2.098819 & .9166884 & -2.29 & $0.022 * *$ & -3.895496 & -.3021432 \\
\hline Craa & -1.884239 & 1.010618 & -1.86 & $0.062 *$ & -3.865014 & .0965356 \\
\hline Extns & 2.453423 & 1.123667 & 2.18 & $0.029 * *$ & .2510768 & 4.65577 \\
\hline Agrinp & -1.697162 & .86886 & -1.95 & $0.051 *$ & -3.400097 & .0057718 \\
\hline Shoc & 3.157063 & 1.2286 & 2.57 & $0.010 * *$ & .7490517 & 5.565074 \\
\hline Famsize & .3221672 & .2140418 & 1.51 & 0.132 & -.097347 & .7416813 \\
\hline Age & -.0125211 & .0564392 & -0.22 & 0.824 & -.1231399 & .0980976 \\
\hline Dismark & -.0623245 & .0576121 & -1.08 & 0.279 & -.1752422 & .0505932 \\
\hline Livestock & .3418422 & .1365745 & 2.50 & $0.012 * *$ & .0741612 & .6095233 \\
\hline Farmsize & -1.26825 & .3594521 & -3.53 & $0.000 * * *$ & -1.972763 & -.5637372 \\
\hline Nfarminc & $3.50 \mathrm{e}-06$ & $9.65 e-06$ & 0.36 & 0.717 & -.0000154 & .0000224 \\
\hline Farminc & -.0000226 & $7.93 e-06$ & -2.85 & $0.004 * * *$ & -.0000382 & $-7.08 \mathrm{e}-06$ \\
\hline Totasset & .0000279 & .0000117 & 2.38 & $0.017 * *$ & $4.95 \mathrm{e}-06$ & .0000508 \\
\hline Constant & .1390963 & 3.129724 & 0.04 & 0.965 & -5.99505 & 6.273242 \\
\hline \multicolumn{7}{|c|}{ Logit Regression } \\
\hline & & & & \multicolumn{2}{|c|}{ Number of observation } & 140.000 \\
\hline \multicolumn{2}{|c|}{ Mean of dependent Var. } & \multicolumn{2}{|c|}{0.579} & \multicolumn{2}{|c|}{ LR chi2(14) } & 139.67 \\
\hline \multicolumn{2}{|c|}{ SD of dependent Var. } & \multicolumn{2}{|c|}{0.496} & \multicolumn{2}{|c|}{ Prob $>$ chi2 } & 0.0000 \\
\hline \multicolumn{2}{|c|}{ Log likelihood } & \multicolumn{2}{|c|}{-95.304848} & \multicolumn{2}{|c|}{ Pseudo R2 } & 0.7328 \\
\hline
\end{tabular}

Source: Own computation from survey data using stata14.2 (2020)

$* * *, * *$ and $*$ shows significance at $1 \%, 5 \%$ and $10 \%$ significance levels, respectively.

Out of the total 14 explanatory variables, 9 variables of which 5 were dummies and 4 continues variables were found to be significantly creating variation on the probability of farmers' resettlement Populations participation.

The coefficients of gender of settler's head, age of settler's heads in years, family size of settler's heads in number, distance from market in kilometers and non-farm income were not statistically significant at all $1 \%, 5 \%$ and $10 \%$ significance levels implying that they were less important in affecting the probability of participation in resettlement Populations .

Nevertheless, under logit model coefficient of the variable have no direct interpretation; as a result, we can use Marginal effect. Logit is all about prediction for interpretation and hence, we must find predicted probabilities to interpret the significant variables. Therefore, interpretation can be derived from the marginal effects after logit. Table 4.3: Estimation of Marginal effects after logit regression

Marginal effects after logit $\mathrm{y}=\operatorname{Pr}($ progptn$)$ (predict)

$$
=0.76763364
$$

\begin{tabular}{|l|l|l|l|l|l|l|l|}
\hline Variable & $\mathbf{d y} / \mathbf{d x}$ & Std. Err. & $\mathbf{Z}$ & $\mathbf{P}>\mathbf{Z}$ & {$[\mathbf{9 5 \%}$ C.I. $]$} & X-bar/mean \\
\hline gen* & -.0283911 & .29758 & -0.10 & 0.924 & -.611638 & .554856 & .957143 \\
\hline educ* & -.3821786 & .14572 & -2.62 & 0.009 & -.667778 & -.096579 & .457143 \\
\hline craa* $^{\text {extns* }}$ & -.3045143 & .15859 & -1.92 & 0.055 & -.615346 & .006317 & .592857 \\
\hline agrinp* & .5150614 & .20673 & 2.49 & 0.013 & .109879 & .920244 & .75 \\
\hline shoc* & -.2734329 & .13802 & -1.98 & 0.048 & -.543953 & -.002913 & .607143 \\
\hline Famsize & .4686937 & .12067 & 3.88 & 0.000 & .232194 & .705193 & .392857 \\
\hline Age & .0574657 & .04044 & 1.42 & 0.155 & -.021805 & .136736 & 8.06429 \\
\hline Dismark & -.0022334 & .01015 & -0.22 & 0.826 & -.02213 & .017663 & 45.3857 \\
\hline livest k & .0609752 & .02561 & 2.38 & 0.017 & .010785 & .111165 & 7.79286 \\
\hline Farmsize & -.2262206 & .07985 & -2.83 & 0.005 & -.382727 & -.069714 & 3.69286 \\
\hline Nfarminc & $6.24 \mathrm{e}-07$ & .00000 & 0.37 & 0.711 & $-2.7 \mathrm{e}-06$ & $3.9 \mathrm{e}-06$ & 22201.4 \\
\hline Farminc & $-4.03 \mathrm{e}-06$ & .00000 & -3.25 & 0.001 & $-6.5 \mathrm{e}-06$ & $-1.6 \mathrm{e}-06$ & 124758 \\
\hline Totasset & $4.98 \mathrm{e}-06$ & .00000 & 2.29 & 0.022 & $7.1 \mathrm{e}-07$ & $9.2 \mathrm{e}-06$ & 181864 \\
\hline
\end{tabular}

$\left.{ }^{*}\right) \mathrm{dy} / \mathrm{dx}$ is for discrete change of dummy variable from 0 to 1 Source: Own computation from survey data using stata (2020) 


\subsection{Interpretation of Significant Variables}

Education status of settler's head (educ): The coefficient of this variable was significant at $5 \%$ level of significance and it is influencing resettlement Populations participation negatively. Our result was showed that educated settler's heads did not more involve in resettlement Populations. Educational attainment by the settler's head could lead to awareness of the possible advantages of resettlement Populations in order to innovation of new site due to enhance settler's incomes.

The marginal effect of the variable shows that keeping all other variables constant at their mean value, educated settler's heads have $38.2 \%$ times less probability of participation in resettlement Populations than those illiterate settler's heads. It is agreed by the finding of Vande Walle (2000) and Melaku (2014).

Credit access (craa): Farmers who have credit access are fewer participants in resettlement Populations. Therefore, access to credit influences the farm settler's participation in resettlement negatively. The study result also reveals that credit access is statistically significant at $10 \%$ level of significance and a change from no credit access to access decreases the probability of the decision to join resettlement Populations other things remain constant, settlers those had access to credit has $30.45 \%$ less probability to participate in the Populations me than their counterpart. It is supported by Muez (2014) and Adugna, (2012).

Access to extension services (extns): access to extension service influences the farm settlers participation in resettlement Populations is positively associated with settler's total income and statistically significant at $5 \%$ of probability level. This result was decided with Adugna, (2012) and Muez (2014). The marginal effect of the variable indicates that settler's access to extension service of the discrete effect change from 0 to 1 in access to extension service decrease the probability of participation in resettlement Populations by 51.51 percentage points than their counterparts others remain constant at their mean value.

Access to agricultural input (agrinp): Farmers who have access to agricultural input can increase their income rather than those who have no access agricultural inputs. So this implies that decrease the participation in resettlement Populations as compared to those who do not have access. The study result also reveals that access to agricultural input is statistically significant at $10 \%$ level of significance and a change from no access to access agricultural input decreases the probability of the decision to join the Populations by $-27.34 \%$ higher than their counterparts, holding other variables constant. It is decided in by the finding of W.Zeweld et, al. (2015).

Shocks (shoc): The coefficient on the shocks (drought \& famine) is significant at 5\% level of significance with positive sign. The result indicates that being exposed to shocks (droughts and famine) increase the likelihood of settler's participation in the resettlement Populations by $46.87 \%$ than settlers not exposed to shocks. It is agreed by A. Arnall (2014).

Livestock: livestock holding, measured in tropical livestock unit, was found to have positive and significant effect at $5 \%$ level of significance on the probability to participate in resettlement Populations. The positive relationship indicates that settlers with larger livestock holding may migrate to new site to feeding his/her livestock's. In the study area marginal effect of this variable shows that as the number of livestock in tropical livestock unit increases from its mean value by one unit, the chance to participate in resettlement Populations increase by $6.098 \%$ points, while keeping all covariates constant at their mean value. The evidence of this finding reflected in contrast to the idea that farmers who have enormous number of livestock are wealthier and have sufficient number of oxen to plough their field timely as a result of which they quickly decide to participate in the resettlement Populations. This is in line with the result of Asayehegn et, al. (2011) and Hadush (2014).

Farmland size in Hectare (farmsize): This is the total land size owned by each sampled settler's heads given in hectare. The result of this study showed that size of farmland has a negative significant effect at $1 \%$ level of significance on the probability of farmers' decision to participate in resettlement Populations. Farmer settlers that had large farm size did not participate in resettlement Populations since he/she has sufficient land used for mixed farming system both crop production and livestock rearing. The marginal effect of this variable reveals that, a marginal change in farm size from the average of 3.693 hectare is associated with a $22.62 \%$ points decrease in Populations participation, keeping other variables constant at their mean average. This result against the expectation supported by Asayehegn et al., (2011), as Asayehegn finding settlers having large cultivated land has more income but my finding were against this finding.

Farm income of Settler's (farminc): The coefficient on farm income of the settler's's head is significant at $1 \%$ of significance level with negative sign. The marginal effect of this variable shows that as farm income from mixed farming source increases from mean value (124758.2) by one Birr, the probability of participation in resettlement Populations less by $4.03 \times 10^{-6}$ percentage $(-0.000403 \%)$ than their counter parts, while other variables were kept constant at their mean value. The result of this finding is in line with the findings of Jamal Haji \& Mohammed Aman (2013).

Total asset owned by settler's (totasset): Settler's total asset was found to have a positive effect on the Populations and significant influence on the probability of participation in resettlement Populations of the settler's heads. Financial and social resources were to some extent available, while natural capital like land resource was the abundant assets for each sampled settlers in the study site as the researcher discussed with respondents. This 
variable is statistically important at 5\% level of significance. The marginal effect results showed that a one Birr increase in total asset of settler's heads from the average/mean 181,864increases the likelihood of participates in resettlement Populations by $4.98 \times 10^{-6}$ percentage whereas other factors remaining constant.

\subsection{Burden Evaluation and Propensity scores}

Without information on the counterfactual, the next best alternative is to compare outcomes of treated individuals or settlers with those of a comparison group that has not been treated. In doing so, one attempts to pick a comparison group that is very similar to the treated group, such that those who received treatment would have had outcomes similar to those in the comparison group in absence of treatment. Successful burden evaluations hinge on finding a good comparison group (Shahidur R. Khandker,Gayatri B. Koolwal \& Hussain A. Samad, 2010).

Prior to analyzing the burden of resettlement Populations by employ PSM matching algorithms, logit regression model was used as a necessity to identify the Populations participant's annual income in order to understand the importance of resettlement Populations. As indicted in the former sections the dependent variable in this model is a twofold variable indicating whether the settler's head was resettlement Populations participant or non-participant. The model was estimated with STATA 14.2 4.7.

\subsection{Evaluation of Burden of Resettlement on Income of Settler settler's by Propensity Score Matching}

Under this, Propensity score use logit model to estimate the probability of each group i.e., resettlement participants and non-participants as a function of observable covariates. The result of propensity score matching of Populations participant and their counterpart was used to define the common support region. Supplementary, the quality of matching algorithms also identified in orientation to the propensity scores pseudo $\mathrm{R}^{2}$ and significance level of each covariates. Table $\{4.6\}$ shows the logit estimation results or marginal effect after logit of sample settler's head in the Populations were used to create propensity score.

The Pseudo $\mathrm{R}^{2}$ which makes clear to how well the regressors explain the participation probability is 0.7328 for logit model is larger. A large pseudo- $\mathrm{R}^{2}$ value shows that resettlement Populations participants' settlers do have some divergent individuality overall and automatically finding a good match between participants and nonparticipants settlers becomes less challenging. Depending on the propensity score-matching distribution of both resettlement Populations participants and non-Populations participants, the common support region was identified. As shown on table $\{5\}$ below the estimated propensity scores vary between 0.0442142 to 1 for the Populations participant and $1.36 \times 10^{-15}$ to 0.908626 for non-participant.

The common support region is area, which lies between 0.0442142 up to 1 , is larger than that of none Populations participant common support region $\left[1.36 \times 10^{-15}\right.$ to 0.908626$]$. Therefore, settler's who estimated propensity score is less than $1.36 \times 10^{-15}$ and larger than 0.908626 were surplus from common support region. So observations which lie outside this region are discarded from analysis. It is support by (Marco \& Sabine Kopeinig, May, 2008). Thus, 56 settlers from Populations participant were out of the common support region while 25 settlers' heads' were involved in common support region.

Table 4.4: Distribution of estimated Propensity Score matching.

\begin{tabular}{|l|l|l|l|l|l|}
\hline Resettlement Populations & Sample size & Mean & Std. Dev. & Min & Max \\
\hline Total observation & 140 & 0.5791825 & 0.4341378 & $1.36 \times 10^{-15}$ & 1 \\
\hline Participants & 81 & 0.9030572 & 0.1930847 & 0.0442142 & 1 \\
\hline Non-participants & 59 & 0.1345411 & 0.229484 & $1.36 \times 10^{-15}$ & 0.908626 \\
\hline
\end{tabular}

(Source: Own computation survey data, 2020)

\subsection{Matching algorithms}

According to Khandker et al (2010), comparing different matching methods results is one approach to check robustness of average treatment effect. Four matching algorithms (i.e., Nearest Neighbor matching, Radius matching, Caliper matching, and Kernel matching) were checked to choose the best matching methods. The choice of matching estimators was based on pseudo $\mathrm{R}^{2}$, matching sample size; mean test referred to as to balance test and insignificancy of variables in analysis after PS matching. Low pseudo $\mathrm{R}^{2}$ value and large matched sample size is preferable. In order to accept the findings of PSM, it is suggested that the standardized mean difference needs to be at most $20 \%$ and the pseudo $\mathrm{R}^{2}$ needs to be low after the matching process (Rosenbaum, 2005; Caliendo and Kopenig, 2008). In line with those authors, the researcher would be obtained the least amount of pseudo $\mathrm{R}^{2}$ that was $5.5 \%$ and 80 number of matched observation.

Thus depending on the kernel matching criteria, kernel $(0.5)$ was selected in which the mean difference of the two groups explanatory variables were significant, Pseudo $\mathrm{R}^{2}$ is the lowest compared to other matching categories and finally balance 80 sample size. 
Table 4.5: Performance of Propensity Score Matching Estimators

\begin{tabular}{|c|c|c|c|}
\hline Matching estimator Sample size & Balancing test & Pseudo R2 & Matched \\
\hline \multicolumn{4}{|c|}{ Kernel matching } \\
\hline 0.01 & $7.6 \mathrm{e}+14^{*}$ & 1.000 & 65 \\
\hline 0.1 & $126.5^{*}$ & 0.255 & 76 \\
\hline 0.25 & $66.7 *$ & 0.078 & 80 \\
\hline 0.5 & $54.9 *$ & 0.055 & 80 \\
\hline
\end{tabular}

(Source: Own computation survey data, 2020)

Table 4.6: Propensity Score Matching and Covariate balancing.

\begin{tabular}{|l|l|l|l|l|l|l|l|l|l|l|l|}
\hline \multicolumn{1}{|c|}{$\begin{array}{l}\text { T= Treated group } \\
\text { C=Control group }\end{array}$} \\
\hline The whole balance indicators of covariates
\end{tabular}

Source: Own computation from survey data, 2020

As shown in the table 7 above, matching reduce total bias, reduce pseudo $\mathrm{R}^{2}$ from 0.717 before match to 0.255 after match and any difference between the two groups covariates mean in the matched sampled has been reduced and after matching nine variables are significant as before matching and were balanced treated and control group.

Table 4.7: Burden of resettlement Populations participation decision on settler's income (ATT-Average treatment effect on treated)

\begin{tabular}{|l|l|l|l|l|l|l|}
\hline Variable & Sample & Treated & Controls & Difference & S.E. & T stat \\
\hline \multirow{3}{*}{ Totinc } & Unmatched & 133555.914 & 115582.22 & 17973.6932 & 6351.13923 & 2.83 \\
\cline { 2 - 7 } & ATT & 144465.476 & 115282.83 & 29182.6463 & 15933.3126 & 1.83 \\
\hline
\end{tabular}

Source: Own computation from survey data, 2020

Average Treatment effect on the Treated (ATT) was estimated depending on Kernel (0.5). The Kernel (0.5) algorithm estimated the average annual income of the matched treated settler's farmers to be $1,44,465.476 \mathrm{ETB}$ and of the matched control of settler's head farmers to be1, 33,555.914ETB. Hence, the ATT for that reason resettlement Populations participant was received 29, 182.6463ETB annual income. In summary, the empirical findings suggest that involvement of resettlement Populations participation is enhanced settler's annual income for treated settlers in a significant way. This is supported with the finding results of Adugna (2012), Jamal Haji and Mohamed Aman (2013).

\section{CONCLUSION S AND RECOMMENDATIONS}

\subsection{Conclusions}

Resettlement is a recovery liberate to some of the world's most vulnerable displacement. From the research findings, it could be concluded that resettlement Populations is play a fundamental role in increase of settler's income in the study area due to resettled in favorable site. Farmers settlers have confirmed that they were benefit greatly from these resettlement Populations and they had been improved their income living standards. To sustain the positive burden s of the Populations and to enable treated settlers make optimum resettlement participation. Purposely, expansion of new habitat and creating additional access of infrastructures and to obtain fertile/virgin land for agricultural productivity on a sustainable basis and thereby increase smallholder farmers' settler's annual income.

The logit regression shows that from the fourteen variables included in the analysis, nine of them were significantly affecting the settlers those participating in the Populations me. Shocks (drought and famine) and farm land size of settler's heads were the more susceptible for the Populations me participation. Settler's heads in the study site were not more educated rather than they were performing agricultural and non agricultural tasks to achieving enough income for stay alive.

Generally resettlement Populations me in the study site attained a positive burden on the resettlement Populations participant settlers annual income in improving livelihood like physical asset, natural asset and stipulation of social services like human health service by constructed health center in the study site, health extension service at each Kebeles, agricultural extension service, veterinary health post service at each Kebeles, and as well as availability of all weather road connecting each rural Kebeles of the study site and other resettlement sites in the study area. This study concluded that, participation in resettlement Populations had been a deep burden on improving the annual income of settler's farmers in the study site. 


\subsection{Recommendations}

This study had been indicated that involvement in resettlement Populations enabled farmer settler's to increase their annual income. Even though, the detailed studies selection of non-Populations participants from original places is the best way for comparison as a control group. Regarding the burden of resettlement Populations on settler's income, the following main points needed to be considered as a possible policy implications forwarded in order to improve the goal of resettlement Populations for the rural settler's.

$>$ The study showed that most of the farmers settlers head in this study were depending on agricultural production or obtaining their income from faming activities rather than non-farm income due to low diversification of non -farm activity during comparison with farm income in study area. So it is better if local or regional government giving more attention to improve source of income for rural settler's.

$>$ Farmers need modern agricultural inputs. However not adapting more utilization of all modern agricultural inputs such as improved seed varieties, improved animal breeds for milk, and meat and poultry production for egg, commercial fertilizer and different chemicals. The fact is that the farmers could not have enough money to buy all the required agricultural inputs on cash and lack of habit to use short-term credit from financial institutions in the last cropping seasons. So, it is necessary for the national and regional policy makers to assess and find out ways in which farmers to get the tradition of use credit service for purchase of agricultural inputs in order to produce excess product for food achievement.

$>$ Settler's head's education level was found to be negatively significant determinant of the resettlement Populations participation. This shows that educated settlers had enough potential to changing their environment as it is favorable to survive. Therefore, government will gives a great attention as the farmers should be educated by a means that fits with their living condition, such as adult education.

$>$ Shocks is one of the main determinant cause of resettlements Populations participation as the researcher undertook analysis from sampled respondents in the study area; therefore, favorable environment should be improved by concerning body to enable farmers easily stabilize their surroundings to living.

$>$ In each three study kebeles development agents were assigned for peasant association to give extension service. Those assigned DA's were only giving theoretical advice for the farmers which was not practically supported and show. It is obvious that extension service provision in training and practical demonstration of farmers has a great contribution to increase production and productivity of the farmers in order to improve their annual income. As a result, it is more important to redesign policy measures for farmers training centers (FTCs) as a practical training and demonstration center of research outputs support level as per the national level farmers training Populations to build up the producing capacity of the farmers to increase their income.

$>$ Large cultivated land size in the study area were held by economically inactive settlers heads rather than economically active farmer settlers, so it is better if local government or other concerned body readjusting the farm land allocation.

$>$ Livestock were the major source of income in the study area but the farmer settlers were little knowledge about livestock rearing and using modern technology like animal breeding system, it is better if concerning body make awareness regarding to how the farmers increase livestock rearing by the way of modern technology for enhance their annual income.

$>$ During data collecting survey supervision, key informants interview and FGD final result, it was observed that the study area has a potential of commercialization farm land. To increase rural settler's farmer's annual income, it requires the local government, agriculture development office, development center offices, the policy makers and other concerned parties has crucial role interest to aware and building the capacity of the farmers to use these potential resources effectively and efficiently.

$>$ Generally, as the study showed that resettlement Populations is the vital alternative to overwhelm the shortage of income and the rural access of land for agricultural production by providing virgin or unutilized cultivable land and accessing necessary basic infrastructural facilities within the intra-regions. Again to enhancing the settlers total fixed asset in the study area the concerned body would be take appropriate action to design incorporated development strategy by creating common feeling in wise utilization of the existing resources under sustainable way.

\section{REFERENCES}

Adugna, M. (2012).Burden of Resettlement Populations me on the Livelihood of Seetlers the case of Sassiga District of East Wallaga Zone, Oromia Regional State, Ethiopia.Haramaya : Haramaya University.

Ahmed Mohammed, (2005). Resettlement, Socio-Economic and Environmental Burden Evaluation: The case of Haro Tatessa Resettlement Site .Research Project Workshop Forum for Social Studies.

Alula Pankhrust, (2004). Long Term Implication of Resettlement in Ethiopia:The proceedings of Workshop by the Ethiopian Socilogist, Social workers Anthropologists and UNEUFE: Addis Ababa. and Implication approach.Bulletin of Forum for Social Studies(FSS).1:(3)8-12. 
Amemiya T. (1981). The modified second-round estimator in the general qualitative response model. J. Econometrics 5:295-9. 1977.

Arnall (2014) "A Climate of Control: Flooding, Displacement and Planned Resettlement in the Lower Zambezi River valley, Mozambique”, The Geographical Journal, 180, 2, 141-150.

Asayehegn, K., Chilot, Y., and Sundar, R. (2011). Effect of small-scale irrigation on the income of rural farm settlers: the case of Laelay Maichew district, Central Tigray, Ethiopia: Journal of Stored Products and Postharvest Research Vol. 2(10), pp. $208-215$

Asrat, T. (2009). The Dynamics of Resettlement with reference to the Ethiopian Experience. Ireland: Kimmage Development Studies Centre.

Berhane, K. (2003) Resettlement and the Quest for Food Security in Ethiopia, MEDREK,Vol.1,No.3,2-7.

Bisht. TC (2009) Development-induced displacement and women: The case of the Tehri Dam, India. Asia Pacific Journal of Anthropology 10:301-317

Caliendo M, Kopenig S. (2008). Some practical guidance for the implementation of propensity capital interactions in rural vietnam. Policy Research Working Paper. 2425. The World Bank, Washington D.C.

Chimhowu, A and Hulme, D. (2006).Livelihood dynamics in planned and spontaneous resettlement.

CSA,(2008) National Population and Housing Census of Ethiopia, Addis Ababa, Ethiopia.

Dagne, M., \& Fisher, Ch. (2015). Collective action and aspiration: the burden of cooperatives on Ethiopian farmers' aspiration. Piette universita, 5, 39100, Bolzano, Italy.

Desalegn R. (2003b). Resettlement in Ethiopia: The Tragedy of Population Relocation in Development in Africa (Volume 13, No.1, 2011).

Desalegn R.(2003a,). Access to Resource and Livelihood Insecurity.Forum for Social studies.

Desalegn (2018) "The Social Reproduction of Marginalization among the Kumpal-Agaw in Northwest Ethiopia" Pp 139-156 in The State of Status Groups in Ethiopia: Minorities between Marginalization and Integration, edited by Susanne Epple. Broschur: Reimer. Development and Change, 33 (4) (2002), pp. $709-732$

Desalegn and Gebre, (2005).Differential reestablishment of voluntary and involuntary Abebaw Abiyu, Mesfin Tebeje and Ermias Mekonnen.(2015). Determinants of small-scale irrigation utilization by smallholder farmers' in rift valley basin, Wolaita zone, Ethiopia.Journal of Natural Sciences Research. 5(21): 2229-3180.

Dwivedi (2017) Models and Methods in Development-Induced Displacement

Ellis, F. (2000).Rural Livelihoods and Diversity in Developing Countries, New York, Oxford University Press.

FAO.(2016). Addressing Rural Youth Migration at its Root Causes: A Conceptual Framework. Social Policies and Rural Institutions Division. Rome, FAO. 74 pp. (also available at http://www.fao.org/3/a-i5718e.pdf).

Galipeau BA, with Ingman M and Tilt B. (2013) .Dam-Induced Displacement and Agricultural Livelihoods in China's Mekong Basin, Human Ecology , p.439.

Gebrehaweria Gebregziabher, Meredith A. Gardiano, Simon Langan J. and Regassa Namara.(2014). Economic analysis of factors affecting motor pump irrigation adoption in Ethiopia.Academic Journal, Journal of Development and Agricultural Economics. 4(3): 257-266

Genanew, A. (2011). Livelihood of Rural Settlers in Resettlement Areas: the Case Study from Quara Woreda of North Gondar Zone, Amhara Region. Addis Ababa: Addis Ababa University: Institute of Development Studies Center for Rural Development Studies.

GFDRE (2001) Rural Development Policies, Strategies and Instruments,[On line]. Available from: www.mfa.gov.et/Miscellanies.php-19k-[17th June 2007]. in Zimbabwe: converging and vulnerable. World Development 34 (4):728-750.

Gujrati, D. (2004). Basic Econometric, (4th Ed.). The McGraw-Hill Companies, New York.

Hadush Hailu. (2014). Adoption and Burden of micro Irrigation on Settler's Income: The case of Eastern Tigray (Doctoral dissertation, Mekelle University).

HAILE, F. T. (2007). Land Degradation Assessment At Idris Resettlement Scheme, Kafta Humera Woreda,Western Zoneof Tigray,Ethiopia. Addis Ababa: Ababa University.

Heckman, (1997).Matching as an econometric evaluation estimator: Evidence from evaluating a Job training Populations . Rev. Econ. Stud. 64 (4) 604-653.

Heggelund, G. (2010). Resettlement Populations mes and environmental capacity in the three gorges dam project. Dev. Chang., 37, 179-199.

Imbens, G.W. (2000). The Role of the Propensity Score in Estimating Dose Response Functions. Biomerika,87(3): 706-710.

Ina Strøm (2017), Syrian refugees start a new life in Norway through resettlement, Amnesty International 20 October 2015, available at:http:// www.refworld. Org/docid /5629ef6f4. Html [accessed 29 April 2017]

Jamal Haji \& Mohammed Aman (2013).Burden analysis of Mede Telila small scale irrigation scheme on settler's Poverty alleviation; International Journal of Development and Economic sustainability, Haramaya, Ethiopia.

Kassahum, Berhanu .(2000). Resettlement: A Strategy for Vulnerable Groups? In Zenork Tadessa ed. In Issue In Rural Development: Proceedings of the Inaugural, Workshop of Forum for Social Studies, FSS, Addis Ababa. 
Learning Center.

Kassahun A, Shiferaw W. And AdbunasirY.(2017). Burden of Intensive Farming Practice on Water Resources: Implication for Human and Livestock Drinking, Sinana District, South East Ethiopia. Journal of Hydrogeology and Hydrologic engineering. 6(1): 165-172.

Koenig D (2014) Reconstructing and improving livelihoods among the urban displaced: Lessons from Mumbai, India. Page Lose to Gain: Is involuntary resettlement a development opportunity?

Kyomugasho M. (2016). Oil industry in Uganda: The socio-economic effects on the People of Kabaale Village , Hoima, and Bunyoro Region in Uganda Lancang River, Procedia Environmental Sciences 2, 2010, p.709711

Lechner, M.(2001). Identification and Estimation of Causal Effects of Multiple Treatments under the Conditional Independence Assumption in Econometric Evaluation of Labor Market Policies, ed by M. Lechner and F. Pfeiffer, Physica-verlag, Heidelberg.

Leuven and Sianesi (2003).Leuven, E. and Sianesi, B. (2010) PSMATCH2: Stata Module to Perform Full Mahalanobis and Propensity Score Matching, Common Support Graphing, and Covariate Imbalance Testing. http:// Econ Papers.repec.org/ RePEc:boc:bocode: s432001Livelihood and Ethnic Relations in Metekel, North Western Ethiopia. PhD Dissertation,

Maddala, G. (1997), Estimation of short run and long run elasticities of energy demand from panel data using shrinkage estimators. Journal of Business and Economic Statistics 15, 90-100.

McDonald, K. S., Hobday,A. J., Fulton,E.A.\& Thompson, P. A. (2018). Interdisciplinary knowledge exchange across scales in a globally changing marine environment. Global Change Biology, 24(7), 3039-3054.

Melaku A., Abera A., Bezuayehu K, Endalkachew N., and Abayneh M. . (2014). Serum Zinc deficiency and associated factors among pre-ART and on-ART adults at Felege Hiwot Referal Hospital, Bahir Dar, North West Ethiopia. International Journal of Nutrition and Food Science 3(4):311-317. migrants: the case of Metekel settlers in Ethiopia. In African study monographs, Vol. 23, No. 1, pp. 31-46.

Mengistu Woube. (2005). Effects of Resettlement schemes on Biophysical and Human Environments: The case of Gambella Region, Ethiopia. Universal Publishers, Boca Raton, Florida, USA.

Muez. (2014). The Burden of Small-Scale Irrigation on Rural settler's Food Security: The case of Emba Alaje woreda. Master's thesis, Mekelle University,Ethiopia

Mwiza, J. N.,( 2010). Is the SADC Tribunal under judicial siege in Zimbabwe? Reflections on Nations Emergencies Unit for Ethiopia.

NMUN.NY. (2016).World Food Populations me Background Guide 2017.The 2017 National Model United Nations (P. P25). New York City, Ny, Usa: Nmun/Ncca.

Ogwang et al. (2018b) Ogwang T, Vanclay F, van den Assem A (2018b) Burden s of the oil boom on the lives of people living in the Albertine Graben region of Uganda. Extractive Industries and Society 5:98-103

Ogwang T, Vanclay F, van den Assem A (2018a) Burden s of the oil boom on the lives of people living in the Albertine Graben region of Uganda. Extractive Industries and Society 5:98-103

Ohta, I and Gebre, Y. (2005). Displacement risks in Africa: refugees, resettlers and their host Oromia Region in People, space and the state: migration, resettlement and displacement in

Quetulio-Navarra M, Niehof A, Van der Horst H, van der Vaart W (2014) Short-term risk experience of involuntary resettled settlers in the Philippines and Indonesia. Habitat International 41:165-175

Rosenbaum P.R., (2005) Observational Studies, Springer, New York.

Shahidur R. Khandker,Gayatri B. Koolwal \& Hussain A. Samad. (2010). Quantitative Methods and Practices: Handbook on Burden Evaluation. Washington DC 20433: The World Bank(WB)-1818 H Street NW.

Sherbinin A, Castro M, Gemenne F (2010) Preparing for Population Displacement and Resettlement Associated with Large Climate Change Adaptation and Mitigation Projects. Bellagio Workshop: 1-11

Shiferaw, A., (2017) and D. Hailu. (2016), "Job Creation and Trade in Manufactures: Industry Level Analysis Across Countries," IZA Journal of Labor \& Development (forthcoming).

Sikka, G. and Mathur, V, (2015) "Women and Environment: Understanding the Essentialist Linkage for Environmental Sustainability" in Vishwa Raj Sharma (ed.), Contemporary Environmental Issues: Vulnerability and Resilience, Research India Press: New Delhi, ISBN NO. 978-93-5171-035-6

Terminski, B.(2013). Development-Induced displacementand Resettlement: Theoretical Frameworks And Current Challenges. Geneava: Oxford Refugee Centre.

Tilt B. and Gerkey D. (2016). Dams and Population Displacement on China's Upper Mekong River: Implications for Social Capital and Socio-Ecological Resilience, Global Environmental Change p.153.

UNHCR, (2012). The United Nations Refugee Agency Resettlement Learning Populations me, Global

UNHCR.(2011 \& 2017). UNHCR Resettlement Handbook: Division of International Protection. Geneva - Revised edition July 2011: UNHCR- the UN refugee agency.

UNHCR.(2014). Resettlement Learning Populations me. UN: the UN refugee agency.

Van de Walle (2000): Are returns to Investment lower for the poor? Human and physical 
Wang P with Wolf S, Lassoie J and Dong S. (2013), a framework for social burden analysis of large dams: A case study of cascading dams on the Upper-Mekong River, China. J. Environ.

Weldesilassie, A. B. (2014) Building a Resilient City to Water Mediated Climate Change: Policy and Institutional Options. Research Report. Addis Ababa: Ethiopian Development Research Institute.

Wilmsen B, Webber M, Yuefang D (2011) Development for whom?rural to Urban resettlement at the three Gorges Dam, China. Asian Studies Review PP, 21-42.

Wilmsen, B. and Webber, M. (2015). What can we learn from the practice of development- forced displacement and resettlement for organized resettlements in response to climate change? Geoforum 58(1):76-85.

Yankson PWK, Asiedu AB, Owusu K, Urban F, Siciliano G (2018) The livelihood challenges of resettled communities of the Bui dam project in Ghana and the role of Chinese dam-builders. Development Policy Review 36:O476-O494

Yntiso, G. (2002). Differential reestablishment of voluntary and involuntary migrants: the case of Metekel settlers in Ethiopia. Graduate School of Asian and African Area Studies, Kyoto University African Study Monographs, 23(1): PP 31-46.

Zeleke, T. (2014). The Contribution of Rural Resettlement to the Livelihoods of Settlers in Ethiopia: A Case of Essera District Resettlement Schemes in SNNPR. Public Policy and Administration Research, Vol.4, No.5.

Zeweld, W., Van Huylenbroeck, G., Hidgot, A., Chandrakanth, M.G. and Speelman, S. (2015). Adoption of smallscale irrigation and its livelihood burden s in northern Ethiopia. Irrigation and Drainage 64(5): 655-668 